\title{
PIGMENTS CONTENT IN DIFFERENT PROCESSED EDIBLE WILD PLANTS
}

\author{
Baiba Ozola $^{1 *}$, Ingrida Augspole ${ }^{2}$, Mara Duma ${ }^{1}$ \\ ${ }^{1}$ Department of Chemistry, Faculty of Food Technology, Latvia University of Life Sciences and Technologies, \\ Liela iela 2, Jelgava, Latvia, e-mail: baiba.ozola@llu.lv \\ ${ }^{2}$ Institute of Soil and Plant Sciences, Faculty of Agriculture, Latvia University of Life Sciences and Technologies,
} Liela iela 2, Jelgava, Latvia

\begin{abstract}
Natural colours of wild plants are similar to artificial pigments, for example: $\beta$-carotene and chlorophyll. The aim of research was to investigate the effect of drying or freezing on the colour intensity and pigments content in leaves of edible wild plants - stinging nettle (Urtica dioica L.), common goutweed (Aegopodium podagraria L.), dandelion (Taraxacum officinale L.) and chickweed (Stellaria media L.) grown in early spring in Latvia. Samples were gather in May 2018. Pigments (total chlorophylls, chlorophyll $a, b$ and total carotenoids) content in the ethanol extracts of fresh, frozen and dried leaves was analysed with spectrophotometer, but the colour was measured in CIE L*a*b* system. The experimental results showed significantly higher content of total chlorophylls and carotenoids in fresh $\left(1.64 \pm 0.14\right.$ and $\left.0.81 \pm 0.02 \mathrm{mg} \mathrm{g}^{-1} \mathrm{DW}\right)$ and frozen $\left(2.08 \pm 0.12\right.$ and $\left.0.94 \pm 0.05 \mathrm{mg} \mathrm{g}^{-1} \mathrm{DW}\right)$ nettle leaves. Freezing process stimulates the higher amount of pigments from all analysed plants. It was observed, that the content of pigments decreased about for three times after drying process. Chlorophyll $a / b$ was higher in goutweed leaves independently of processing. The obtained results demonstrate that the significant differences were found between fresh, frozen and dried plant leaves colour components $\mathrm{L} * \mathrm{a} * \mathrm{~b} *$
\end{abstract}

Keywords: pigments, colour, edible wild plants

\section{Introduction}

During the last years, interest about wild leafy vegetables has significantly increased in many countries, including Latvia. It is known that they provide high levels of phytonutrients. The chemical composition of wild plants has considerable interest due to their properties regardless humans' health (Khanam et al., 2012). These plants could be used as functional foods, because they contain biologically active food compounds and could provide health benefits (Salvatore et al., 2005).

About 1000 plant species of the nettle family (Urticaceae) are popular in the world, but only two nettle species are found in Latvia: Urtica dioica L., often called common nettle or stinging nettle, and Urtica urens L. known as annual nettle (Zeipina et al., 2015). Nettle leaves contain vitamins and other biologically active compounds which have antioxidant activity, (Guil-Guerrero et al., 2003; Kukric et al., 2012). Dandelion (Taraxacum officinale L.) leaves are known as medicinal herb for long time, mainly due to its hypoglycaemic activities (Schütz et al., 2006). Dandelion are good origin of vitamins (provitamin A, vitamin C) and mineral elements (Gupta, Rana, 2003). Many researchers have investigations on chemical composition (Shi et al., 2008; Gatto et al., 2011; Dias et al., 2014), antioxidant properties (Hu, Kitts, 2003) of dandelion and characterized its biological value (Escudero et al., 2003). Common goutweed (Aegopodium podagraria L.) is well known wild plant, growing in Europe and Asia, very often in dark and shady places, and its leaves could be used like spinach. It is also used for medical purposes - for prevention of cancer, inflammation, arthritis and nervousness (Duke et al., 2002; Prior et al., 2007). Chickweed (Stelleria media L.) is a plant, which belongs to the order Caryophyllales, and very common in gardens, countryside and roadside. In folk medicine is used as a heart remedy, as diuretic, but new leaves are used for salads and soups. The presence of chlorophyll pigments determined the green colour of plants. Plant pigments - chlorophylls and carotenoids take part in metabolism of light energy, as well as catalyse formation of carbohydrates. Chlorophylls containing products can be used as a food colorant (E 140) and healthy constituent of our diet. Newest scientific studies have highlight the anti-carcinogenic and anti-mutagenic effect of chlorophylls containing compounds (Mishra et al., 2011). The chemical composition and chemical properties of chlorophylls provide the ability to prevent lipid oxidation in food (Daood, 2003). Due to antioxidative properties of chlorophylls and carotenoids they could participate in prevention of oxidative stress, cardiovascular diseases, cancer and other health problems (Žnidarčič et al., 2011). Whereas chlorophylls can be considered as indicator of plant's quality, content of chlorophylls in plants indicates the nutritional value of them. McQuistan et al. (2012) noted that plants colour, is also an indicator of the vegetable pigment concentration. There are data about using content of chlorophylls as parameter to evaluate the effect of pollutants on plants (Petrova et al., 2017). Plants which are growing in polluted environment have decreased content of chlorophylls and carotenoids, the structure of their chloroplast membranes are changed so that intensity of photosynthesis is decreased (Schubina, 2011).

The application of preservation methods like freezing and drying, gives possibility to retain plants quality and could use it out of seasons. Drying is well known method for plants preservation and can be done in different ways - in open air, by direct sunlight, in drying ovens etc. (Muller, Heindl, 2006). Drying process could effected many enzymatic reactions in fresh plants. It may result in remarkable variations in content and 
structure of biologically active compounds (Puranic et al., 2012). There are many scientific researches regarding the effect of drying process on the content of plant pigments, showing that different drying methods could give dissimilar result (Rocha et al., 2011; Puranik et al., 2012; Droštinova et al., 2015).

Freezing is one of the oldest methods used for food preservation providing that products are preserved for longer time. During freezing the most enzymes are inactivated, chemical reaction rate is reduced thus ensuring maintaining nutritional value of products, as well as allowing preserving taste and texture (Delgado, Sun, 2000).

The aim of research was to investigate the effect of drying or freezing on the colour intensity and pigments content in leaves of edible wild plants - stinging nettle (Urtica dioica L.), common goutweed (Aegopodium podagraria L.), dandelion (Taraxacum officinale L.) and chickweed (Stellaria media L.) grown in early spring in Latvia.

\section{Materials and Methods}

\section{Plant materials}

Samples of whole leaves of chickweed (Stellaria media L.), common goutweed (Aegopodium podagraria L.), dandelion (Taraxacum officinale L.) and stinding nette (Urtica dioica L.) were grown in Latvia, Zemgale region and harvested in April 2018. In the same day wild plants samples were developed for investigation. The wild plant samples were freezing for seven days at $-18 \pm 2{ }^{\circ} \mathrm{C}$ and drying at $85 \pm 1{ }^{\circ} \mathrm{C}$ for $48 \mathrm{~h}$ in ventilated thermostat.

Determination of total carotenoids, chlorophyll a and chlorophyll $b$

The homogenized wild plants samples were weighted $(0.5 \pm 0.0001 \mathrm{~g})$ in a glass conical flask $(100.0 \mathrm{~mL})$, $10.0 \mathrm{~mL}$ of $96 \%$ ethanol was added and the test conical flask were held for 20 min with occasional shaking at $+19 \pm 2{ }^{\circ} \mathrm{C}$ room temperature. The extracts were filtred (paper No 89) and extraction was done in four replicates. The obtained infusion was analysed content of total carotenoids (xanthophylls and carotenes) $\mathrm{c}_{\mathrm{c}+\mathrm{x}}$, chlorophyll a chla, chlorophyll b $c_{\text {Chlb }}$ by spectrophotometer JENWAY 6300 at wavelengths 470, 649, $664 \mathrm{~nm}$. Chlorophylls and total carotenoids content were calculated according to the following formulas (Sumanta et al., 2014).

Chlorophyll $a\left(\mathrm{mg} \mathrm{mL}^{-1}\right)$ :

$$
c_{\text {Chla }}=13.36 A_{664}-5.19 A_{649}
$$

Chlorophyll $b\left(\mathrm{mg} \mathrm{mL}^{-1}\right)$ :

$$
c_{C h l b}=27.43 A_{649}-8.12 A_{664}
$$

Total chlorophylls $\left(\mathrm{mg} \mathrm{mL}^{-1}\right)$ :

$$
c_{a+b}=c_{C h l a}+c_{C h l b}
$$

Total carotenoids $\left(\mathrm{mg} \mathrm{mL}^{-1}\right)$ :

$$
c_{c+x}=\frac{1000 A_{470}-2.13 c_{C h l a}-97.63 c_{C h l b}}{209}
$$

Ratio between chlorophyll $a$ and chlorophyll $b$ :

$$
R_{a / b}=\frac{c_{C h l a}}{c_{C h l b}}
$$

Ratio between chlorophylls and carotenoids:

$$
R_{a+b} /_{c+x}=\frac{c_{a+b}}{c_{c+x}}
$$

Results of the study were pronounced as $\mathrm{mg} \mathrm{g}^{-1}$ of fresh weight (FW) or dry weght (DW) wild plants material.

\section{Colour analysis}

Colour of wild samples were fixed in CIE L*a*b* colour system using a colorimeter ColorTec PCM (Accuracy Microsensors Inc., USA). Seven random wild plant leaves were measured and the mean values were calculated for each sample (Coultate, 2009). Herbal samples before analysis were placed in a glass Petri dish with a lid (external diameter $50 \mathrm{~mm}$, inner $60 \mathrm{~mm}$ ) and the intensity of the herbal colour was measured on the surface of the dish. Color analysis were repeated on different randomly selected places at the surface of each wild plant samples $(\mathrm{n}=8)$.

Moisture content analysis

The A\&D Company, Limited Moisture Analyser (AND MX-50, Japan) was used for moisture content determination in plant materials according to Razak et al. (2006).

\section{Statistical analysis}

Results of the study are means of four parallel measurements and were calculating by Microsoft Excel 2016. Analysis of ANOVA variance was used to define differences amid samples. The result differences were finded as significant at $\mathrm{p}<0.05$.

\section{Results and Discussion}

Important functional food component are leafy plants. They contain a lot of vitamins, minerals and biologically active compounds. These plants also contain several types of photosynthetic pigments - chlorophylls and carotenoids (Kimura, Rodriguez-Amaya, 2002).

Chlorophyll $a$ value in fresh analysed plant samples differed significantly $(\mathrm{p}<0.05)$ and varied between $0.426 \pm 0.006 \mathrm{mg} \mathrm{g}^{-1} \mathrm{FW}$ and $1.229 \pm 0.01 \mathrm{mg} \mathrm{g}^{-1} \mathrm{FW}$ (Figure 1). The best source of chlorophylls in spring time is fresh nettle leaves where the content of chlorophyll $a$ and $b$ was determined $1.229 \pm 0.008$ and $0.411 \pm 0.002 \mathrm{mg} \mathrm{g}^{-1} \mathrm{FW}$, respectively. The results of our wild edible plant study showed that nettle leaves had the highest content of chlorophyll $a$ and $b$ in fresh and frozen samples. Comparing with other analysed plants it was higher in average two to three times. Our results were similar to data reported by Upton (2013), who noticed that content of chlorophylls in nettles could be $0.08-0.30 \% \mathrm{FW}$. The content of chlorophyll $a$ in frozen samples was the following: frozen stinging nettle > frozen dandelion $>$ frozen common goutweed $>$ frozen chickweed (Figure 1). 


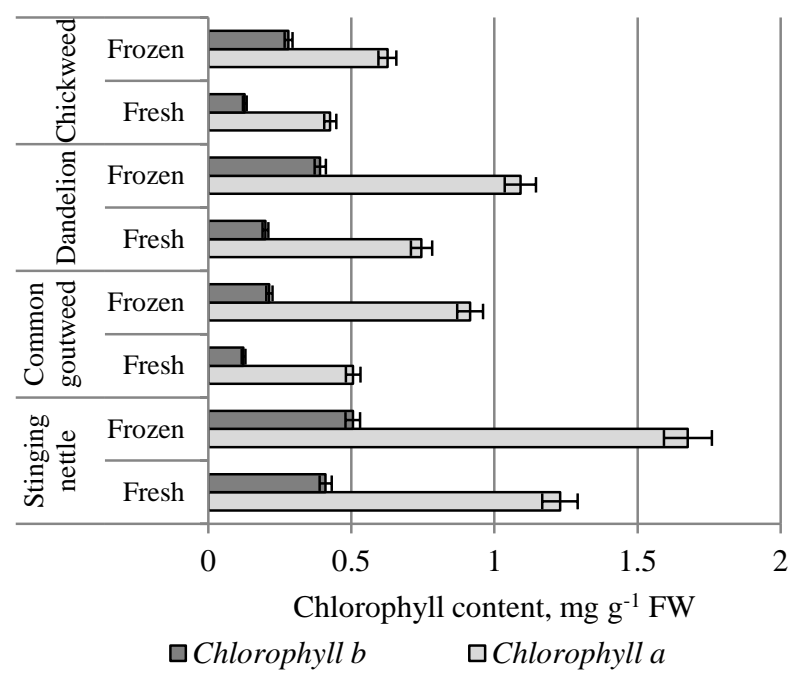

Figure 1. Content of chlorophylls

The data presented in Table 1 reveals the fact that the values of the pigments vary significantly according to used processing method. For comparing the obtained results, all data were expressed to dry weight. The content of dry weight was determined: stinging nettle

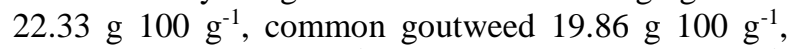

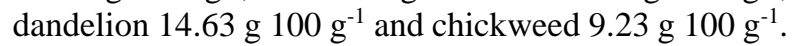
We had observed that after freezing it is possible to extract more pigments from plants compared with fresh materials. Content of chlorophyll $a$ increased from 1.4 times (stinging nettle) till 1.8 times (common goutweed). The increase of chlorophyll $b$ content had similar tendency. It could be explained with the fact, that low temperature promotes a better preservation of chlorophylls. In addition, short freezing time promotes the breakage of plant cells therefore giving possibility to extract more pigments from plants. The changes of chlorophyll content in our study have another tendency in comparison with results in similar studies (Lisiewska et al., 2004), that could be explained by different freezing times used in the studies.
For explaining experimental results, often the ratio of chlorophyll $a$ and chlorophyll $b\left(\mathrm{R}_{\mathrm{a} / \mathrm{b}}\right)$ as well as ratio of total chlorophylls and carotenoids $R_{a+b / c+x}$ are used. In the analysed plants a ratio $R_{a / b}$ ranged from $2.99-4.11$ in fresh samples, 2.24-4.31 in frozen plants or 3.88-4.83 in dried plant material (Table 1).

In all cases this ratio increased after drying. It could be explained with fact that during processing the content of chlorophyll $b$ decreased and therefore the ratio increased. The highest ratio $(a+b) /(x+c)$ was calculated in stinging nettle (4.53) and the lowest in dandelion (4.09). It means that plants were fresh and suitable for experiments because this ratio as an indicator of the plants greenness normally was between 4.2 and 5.0 (Lichtenthaler, Buschman, 2001). Ratio $(a+b) /(x+c)$ can be considered as indicator of senescence, stress, and damage to the plant. Lower values for this ratio confirm this. If the colour of leaves changes, then $(a+b) /(x+c)$ values decreased till 2.5-3.5 (Salehi, Arzani, 2014).

The lowest total chlorophylls content was in common goutweed sample regardless of the processing method, but the highest $14.15 \mathrm{mg} \mathrm{g}^{-1} \mathrm{DW}$ in frozen chickweed (Fig. 2).

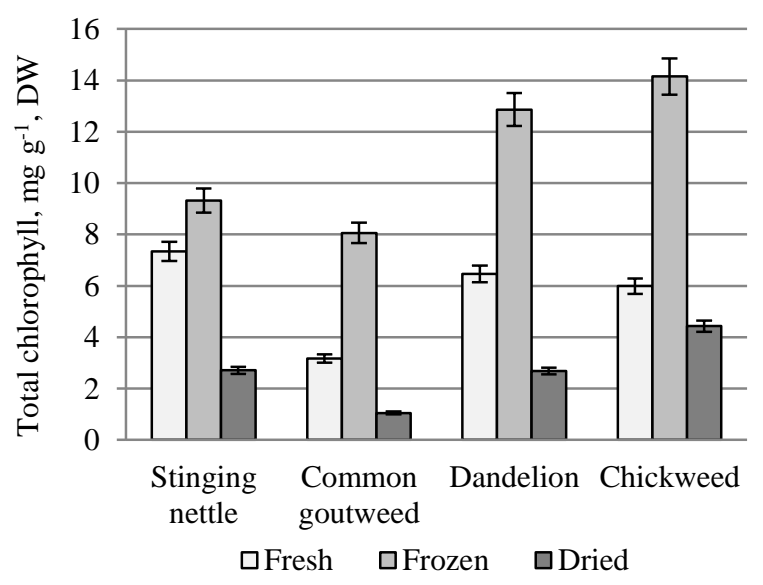

Figure 2. Content of total chlorophylls

Chlorophylls content in plants

\begin{tabular}{|c|c|c|c|c|c|}
\hline Plant material & Sample & ${\text { C Chla, } \text { mg g g }^{-1} \text { DW }}$ & $\mathrm{C}_{\text {Chlb}}, \mathrm{mg} \mathrm{g}^{-1} \mathrm{DW}$ & Ratio, $\mathbf{a} / \mathbf{b}$ & Ratio, $a+b / c+x$ \\
\hline \multirow{3}{*}{ Stinging nettle } & Fresh & $5.56 \pm 0.14$ & $1.84 \pm 0.08$ & 2.99 & 4.53 \\
\hline & Frozen & $7.51 \pm 0.15$ & $2.26 \pm 0.11$ & 3.42 & 4.59 \\
\hline & Dried & $2.23 \pm 0.11$ & $0.51 \pm 0.01$ & 4.31 & 2.85 \\
\hline \multirow{3}{*}{ Common goutweed } & Fresh & $2.55 \pm 0.11$ & $0.62 \pm 0.01$ & 4.11 & 4.28 \\
\hline & Frozen & $4.61 \pm 0.12$ & $1.07 \pm 0.14$ & 4.31 & 4.88 \\
\hline & Dried & $0.87 \pm 0.02$ & $0.18 \pm 0.03$ & 4.83 & 2.33 \\
\hline \multirow{3}{*}{ Dandelion } & Fresh & $5.09 \pm 0.13$ & $1.37 \pm 0.06$ & 3.72 & 4.09 \\
\hline & Frozen & $7.46 \pm 0.14$ & $2.67 \pm 0.12$ & 2.79 & 5.00 \\
\hline & Dried & $2.16 \pm 0.08$ & $0.52 \pm 0.03$ & 4.15 & 2.63 \\
\hline \multirow{3}{*}{ Chickweed } & Fresh & $4.62 \pm 0.09$ & $1.38 \pm 0.11$ & 3.35 & 4.13 \\
\hline & Frozen & $6.78 \pm 0.13$ & $3.03 \pm 0.20$ & 2.24 & 4.90 \\
\hline & Dried & $3.53 \pm 0.11$ & $0.91 \pm 0.03$ & 3.88 & 3.75 \\
\hline
\end{tabular}

Plants contain several photosynthetic pigments, not only chlorophylls, but also carotenoids. The total carotenoids concentrations differed significantly within analysed plant samples and type of processing $(p<0.05)$.
Figure 3 shows the changes of total carotenoids content in analysed plant samples depending on the type of processing. 


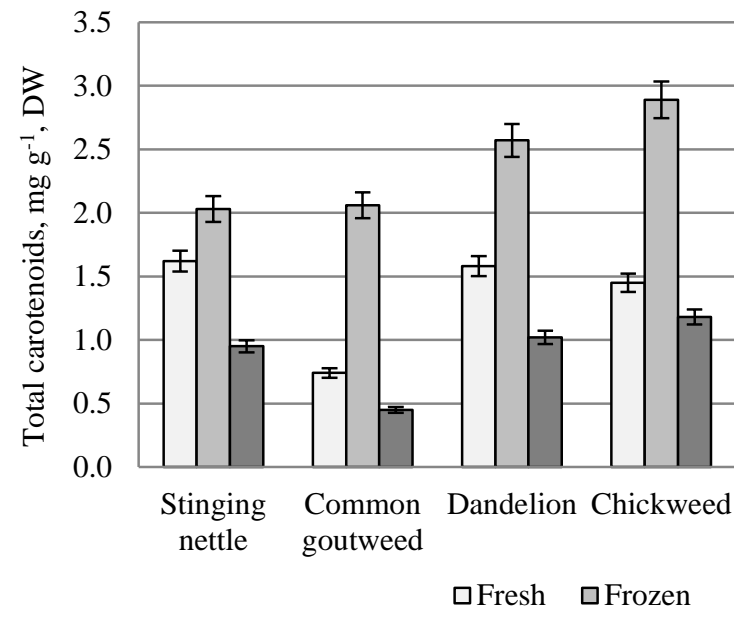

Figure 3. Content of total carotenoids

The content of carotenoids in fresh wild plant samples was from $0.74 \pm 0.03 \mathrm{mg} \mathrm{g}^{-1}$ (common goutweed) till $1.62 \pm 0.08 \mathrm{mg} \mathrm{g}^{-1}$ (stinging nettle). The determined content of total carotenoids in fresh leaves is higher than results reported by Guil-Guerrero et al. (2003) and Upton (2013) who has been reported that the total amount of carotenoids from fresh leaves of nettles was determined $29.6 \mathrm{mg} 100 \mathrm{~g}^{-1} \mathrm{DW}$. Our results are also higher than the data of Žnidarčič et al. (2011) who analysed carotenoids content in fresh dandelion leaves and determined $6.34 \mathrm{mg} 100 \mathrm{~g}^{-1}$. There are many factors - species, variety, cultivar, production practice, as well as environmental growth factors such as light, temperature, and soil properties. The region and conditions for growing the studied plants are very important. This could be the explanation for the variation between our results and those shown in some literature sources.(Van den Berg et al., 2000). On the other hand, the values in our study are in agreement with the data of Rohricht (2007) who find out the content of carotenoids $0.10-0.16 \%$ dry weight nettle leaves.

Similar to chlorophylls, freezing promotes the extraction of total carotenoids, but the influence was significantly lower $(\mathrm{p}<0.05)$. The determined content of carotenoids increased for $25.3 \%$ (stinging nettle), $62.7 \%$ (dandelions), 99\% (chickweed) or 1.8 times (common goutweed) comparing with fresh samples. Comparatively the content of chlorophylls increased from 1.21 times (stinging nettle) till 2.5 times (common goutweed).

The decrease of carotenoids content in dried samples was observed, but for different plants it was different for stinging nettle samples the decrease was for $41.4 \%$, but for common goutweed only $20.7 \%$.

Therefore, freezing is recommended for better prevention of the biologically active compounds. Unfortunately, there is a lack of scientific information regarding chemical composition of common goutweed, dandelion and chickweed. Moreover, there are little research about effects of processing - freezing or drying on the changes of pigments content in non-traditional wild edible plants mentioned above.

It is assumed that the greater intensity of the colour of leafy plants indicates its higher nutritive value (Shibghatallah, Suhandono, 2013). Significant differences were found between the values of the colour components $\mathrm{L}^{*}, \mathrm{a}^{*}$ and $\mathrm{b}^{*}$ of fresh, frozen and dried leafy plants (Table 2).

The highest $\mathrm{L}^{*}$ value, related to the lightness, was found for fresh chickweed and dandelion, respectively $(45.25 \pm 0.16)$ and $(44.40 \pm 0.18)$ (Table 2). The lowest values of this colour parameter were determined for dried stinging nettle samples $(23.44 \pm 0.08)$ (showing a darker colour intensity). For all fresh leafy plant samples the highest $b^{*}$ value were determined. This colour component is related to the yellowness. The highest values of parameter $\mathrm{a}^{*}$ were obtained for dried stinging nettle $(1.34 \pm 0.10)$ and dried chickweed $(1.30 \pm 0.10)$.

This colour component is related to the redness.

It has been found that colour parameters $\mathrm{L}^{*}, \mathrm{a}^{*}$ and $\mathrm{b}^{*}$ are significantly affected by freezing or drying of leafy plant samples.

Colour components in plants

\begin{tabular}{llccc}
\hline \multirow{2}{*}{ Plant material } & \multirow{2}{*}{ Analysed sample } & \multicolumn{3}{c}{ Colour components } \\
\cline { 3 - 4 } Stinging nettle & & $\mathbf{L}^{*}$ & $\mathbf{a}^{*}$ & $\mathbf{b}^{*}$ \\
& Fresh & $42.61 \pm 0.12$ & $0.87 \pm 0.03$ & $20.32 \pm 0.11$ \\
& Frozen & $24.40 \pm 0.10$ & $0.53 \pm 0.01$ & $9.68 \pm 0.07$ \\
& Dried & $23.44 \pm 0.08$ & $1.34 \pm 0.10$ & $4.40 \pm 0.05$ \\
\hline \multirow{3}{*}{ Common goutweed } & Fresh & $38.76 \pm 0.10$ & $0.97 \pm 0.07$ & $19.76 \pm 0.12$ \\
& Frozen & $37.98 \pm 0.09$ & $0.85 \pm 0.05$ & $15.89 \pm 0.10$ \\
& Dried & $28.44 \pm 0.08$ & $1.22 \pm 0.10$ & $13.98 \pm 0.09$ \\
\hline \multirow{3}{*}{ Dandelion } & Fresh & $44.40 \pm 0.18$ & $0.85 \pm 0.08$ & $21.94 \pm 0.15$ \\
& Frozen & $43.43 \pm 0.15$ & $0.81 \pm 0.08$ & $17.85 \pm 0.11$ \\
& Dried & $26.62 \pm 0.10$ & $1.27 \pm 0.14$ & $13.75 \pm 0.09$ \\
\hline \multirow{2}{*}{ Chickweed } & Fresh & $45.25 \pm 0.16$ & $0.78 \pm 0.05$ & $22.34 \pm 0.11$ \\
& Frozen & $42.86 \pm 0.12$ & $0.65 \pm 0.08$ & $14.19 \pm 0.10$ \\
& Dried & $27.41 \pm 0.10$ & $1.30 \pm 0.10$ & $12.79 \pm 0.09$ \\
\hline
\end{tabular}

\section{Conclusions}

As some wild edible plants are very healthy and will provide consumers with necessary pigments and other biologically active substances, but those are highly seasonal, then for preservation, these plants better freeze than dried. Freezing of leafy plant samples promotes 
pigment extraction from them, contrary to that, the dried samples contained three times less pigment. The best source of chlorophylls in spring time is fresh nettle leaves. The ratio between chlorophyll $\mathrm{a} / \mathrm{b}$ was higher in goutweed leaves regardless of processing. Significant differences were determined between the colour components $\mathrm{L} * \mathrm{a} * \mathrm{~b} *$ of fresh, frozen and dried plant leaves.

\section{References}

1. Coultate T. (2009) Food: the chemistry of its components. Cambridge: RSC Publishing, Royal Society of Chemistry, p. 501.

2. Daood H.G. (2003) Chlorophyll. In: Encyclopedia of Food Sciences and Nutrition. Second edition. Caballero B., Trugo L.C., Finglass P.M. (Ed.) Academic Press, p. 1196-1205.

3. Delgado A.E., Sun D.W. (2000) Heat and mass transfer for predicting freezing processes. A Review. Journal of Food Engineering, Vol.47, p. 157-174.

4. Dias M. I., Barros L., Alves R.C., Oliviera B. P. P., Santos-Buelga C., Ferreira I.C.F.R. (2014) Nutritional composition, antioxidant activity and phenolic compounds of wild Taraxacum sect. Ruderalia. Food Research International, Vol. 56, p. 266-271.

5. Droštinova L., Braniša J., Bončikova D., Jomova K. (2015) Effect of drying methods on content of some natural pigments in Urtica Dioica L. and Melissa Officinalis L.. Journal of Microbiology, Biotechnology and Food Sciences, Vol. 5(2), p. 182-185.

6. Duke J.A., Bogenschutz-Godwin M. J., Du Cellier J., Duke P.A.K. (2002) Handbook of Medicinal Herbs, 2nded. CRC Press LLC, Florida, p. 346.

7. Escudero N.L., Arellano M. L., Albarracín S.F.G., Mucciarelli S. (2003) Taraxacum officinale as a food source. Plant Foods for Human Nutrition, Vol. 58, p. $1-10$

8. Gatto M. A., Ippolito A., Linsalata V., Cascarano N. A., Nigro F., Vanadia S., Venere D. D. (2011) Activity of extracts from wild edible herbs against postharvest fungal diseases of fruit and vegetables. Postharvest Biology and Technology, Vol. 61, p. 72-82.

9. Guil-Guerrero J.L., Rebolloso-Fuentes M.M., Isasa M.E.T. (2003) Fatty acids and carotenoids from stinging nettle (Urtica dioica L.). Journal of Food Composition and Analysis, Vol. 16, p. 111-119.

10. Gupta K., Rana M.K. (2003) Salad crops-other types of salad crops. In: Caballero, B. (Ed.), Encyclopedia of Food Sciences and Nutrition, second ed. Academic Press, Oxford, p. 5055-5060.

11. Hu C., Kitts D.D. (2003) Antioxidant, prooxidant, and cytotoxic activities of solvent fractionated Dandelion (Taraxacum officinale) flower extracts in vitro. Journal of Agricultural and Food Chemistry, Vol. 51, p. 301-310.

12. Khanam U.K.S., Oba S., Yanase E., Murakami Y. (2012). Phenolic acids, flavonoids and total antioxidant capacity of selected leafy vegetables. Journal of Functional Foods, Vol. 4, p. 979-987.

13. Kimura M., Rodriguez-Amaya D.B. (2002). A scheme for obtaining standards and HPLC quantification of leafy vegetable carotenoid. Food Chemistry, Vol. 78, p. 389-398.

14. Kukric Z.Z., Topalic-Trivunovic L.N., Kukavica B.M., Matoš S.B., Pavičic S.S., Boroja M.M., Savič A.V. (2012) Characterization of antioxidant and antimicrobial activities of nettle leaves (Urtica dioica L.). Acta Periodica Technologica, Vol. 43. p. 257-272.

15. Lichtenthaler H.K., Buschman C. (2001) Chlorophylls and carotenoids: Measurement and characterization by UVVIS spectroscopy. In: Current Protocols in Food Analytical Chemistry, John Wiley and Sons, New York, p. F4.3.1-F4.3.8.

16. Lisiewska Z., Kmiecik W., Slupski J. (2004) Contents of chlorophylls and carotenoids in frozen dill: effect of usable part and pre-treatment on the content of chlorophylls and carotenoids in frozen dill (Anethum graveolens L.), depending on the time and temperature of storage, Food Chemistry, Vol. 84, p. 511-518.

17. McQuistan T.J., Simonich M.T., Pratt M.M., Pereira C.B., Hendricks J.D., Dashwood R.H., Williams D.E., Bailey G.S. (2012) Cancer chemopreventation by dietary chlorophylls: A 12,000-animal dose-dose matrix biomarker and tumor study, Food and Chemical Toxicology, Vol. 50 (2), p. 341-352.

18. Mishra V.K., Husen A., Bachetti R.K. (2011) Medical uses of chlorophyll: A critical overview. In: Chlorophyll structure, function and medical uses. Nova Science Publishers, Inc. Hauppauge NY 11788, Hua Le and Elisa Salcedo (eds.) p. 177-196.

19. Muller J, Heindl A. (2006) Drying of medical plants. In: Medical and aromatic plants. Rogers R., Craker L., Lange D. (eds.) Springer, p. 237-252.

20. Petrova S., Todorova K., Dakova M., Mehmed E., Nikolov B., Denev I., Stratiev M., Georgiev G., Delchev A., Stamenov S., Firkova L., Gesheva N., Kadirova D., Velcheva I. (2017) Photosynhtetic pigments as parametrs/indicators of tree tolerance to urban environment (Plovdiv, Bulgaria). Ecologia Balcanica, Vol. 9(1), p.53-62.

21. Prior N. M., Lundgaard H., Light M.E., Stafford G.I., Staden J., Jäger A.K. (2007) The polyacetylene falcarindiol with COX-1 activity isolated from Aegopodium podagraria L. Journal of Ethnopharmacology, Vol. 113, p. 176.-178

22. Puranik V., Chauhan D.K., Mishra V., Rai G.K. (2012) Effect of drying techniques on the physicochemical and bioactive components of selected medical herbs. Annals of Phytomedicine, Vol. 1(2), p. 23-29.

23. Razak N.A., Shaari A.R., Nat A.F., Abdullal S. (2014) Effect of leaf moisture content on the herbal quality parameter of Orthosiphon stamineus dried leaf during storage. International Journal of Agriculture Innovations and Research, Vol. 2(6), p. 1131-1136.

24. Rohricht C. (2007) Yield and constituents of greater nettle strains (Urtica dioica, L.). Zeitschrift Fur Arznei \& Gewurzplanzen, Vol 12, p. 3-5.

25. Rocha R.P., Melo E.C., Radunz L.L. (2011) Influence of drying process on the quality of medical plants: A review. Journal of Medicinal Plants Research, Vol. 5(33), p. 7076-7084.

26. Rocha R. P., Melo E. C., Radunz L. (2011) Influence of drying process on the quality of medicinal plants: A review. Journal of Medicinal Plants Research, Vol. 5(33), p. 7076-7084

27. Salehi M., Arzani A. (2014) Evaluation of triticale genotypes for salt tolerance using physiological traits. Emir, Journal of Food and Agriculture, Vol. 26(3), p. 277-283.

28. Salvatore S., Pellegrini N., Brenna O.V., Del Rio D., Frasca G., Brighenti F., Tumino R. (2005) Antioxidant characterization of some Sicilian edible wild greens. 
Journal of Agricultural and Food Chemistry, Vol. 53, p. 9465-9471.

29. Schubina A.G. (2011) Maintenance of chlorophyll and carotinoids in leaves of dandelion medicinal (Taraxacum Officinale) and birches (Betula Pendula Roth) growing in Tambov. [Шубина T.A. Содержание хлорофилла и каротиноидов в листьях одуванчика лекарственного (Taraxacum Officinale) и березы повислой (Betula Pendula Roth), растущих в г. Тамбове]. In: Transactions of the TSU [вестник ТГУ], Vol. 16 (1), p. 353-355, (in Russian).

30. Schütz K., Carle R., Schieber A. (2006) Taraxacum-A review on its phytochemical and pharmacological profile. Journal of ethnopharmacology, Vol. 107(3), p. 313-323.

31. Shi S., Zhang Y., Zhao Y., Huang K. (2008) Preparative isolation and purification of three flavonoid glycosides from Taraxacum mongolicum by high-speed countercurrent chromatography. Journal of Separation Science, Vol 31, p. 683-688.

32. Shibghatallah K., Suhandono V.K. (2013) Measuring leaf chlorophyll concentration from its color: A way in monitoring environment change to plantations. Biological
Physics. In: AIP Conference Proceedings, Vol. 1554 (1), p. 210-213.

33. Sumanta N., Haque C.I., Nishika J., Suprakash R. (2014) Spectrophotometric analysis of chlorophylls and carotenoids from commonly grown fern species by using various extracting solvents. Research Journal of Chemical Sciences, Vol. 4(9), p. 63-69.

34. Upton R. (DAyu R.H.) (2013) Stinging nettles leaf (Urtica dioica $\mathrm{L}$.): Extraordinary vegetable medicine. Journal of Herbal Medicine, Vol. 3, p. 9-38.

35. Van den Berg H., Faulks R., Granado H.F., Hirschberg J., Olmedilla B., Sandmann G. (2000) The potential for the improvement of carotenoid levels in foods and the likely systemic effects. Journal of the Science of Food and Agriculture, Vol. 80, p. 880-912.

36. Zeipiṇa S., Alsiṇa I., Lepse L., Dūma M. (2015) Antioxidant activity in nettle (Urtica dioica L.) and garden orache (Atriplex hortensis L.) leaves during vegetation period. Chemine Technologija. Vol. 1(66), p. 29-33.

37. Žnidarčič B., Ban D., Šircelj H. (2011) Carotenoid and chlorophyll composition of commonly consumed leafy vegetables in Mediterranean countries. Food Chemistry, Vol. 129, p. 1164-1168. 